\title{
Active Debris Removal: Potential Legal Barriers and Possible Ways Forward
}

\author{
Jinyuan $\mathrm{Su}^{* *}$
}

The space environment is unique. Natural decay of debris therein is much slower than pollutants in other environments, so that removal is difficult and expensive. Despites the voluntary implementation of mitigation guidelines, the amount of debris has surged in the last two decades due to increase and diversification of space actors, and the continuing militarization of space. Active Debris Removal has thus become a promising responsive scenario. This article examines key legal barriers to the implementation of removal, such as the lack of legal definition of space debris, ambiguities surrounding the jurisdiction and control over space debris, liability for possible damages caused in removal, and implications for space arms control. It further proposes that more comprehensive registration of space objects, an international catalogue of space debris and an international fund for removal should be promoted. Also, international cooperation should be enhanced to cope with space debris, while space arms control should be strengthened.

\section{Keywords}

Active Debris Removal, Debris Mitigation, Registration, Dual-Use

* This paper is fully revised and updated version of a paper with the same title which was presented at the International Conference on New Challenges of Space Law (Athens, Aug. 28-29, 2015), co-organized by the Department of International \& European Studies, Faculty of Law, National and Kapodistrian University of Athens, Greece and the Institute of Air and Space Law and Centre for Research in Air and Space Law, Faculty of Law, McGill University, Canada. It forms part of the research project 13F057 supported by Shaanxi Provincial Social Science Research Fund, China. Views and errors expressed in this paper, if any, are solely the author's and do not represent the official position of any government or organization.

** Professor at Xi'an Jiaotong University School of Law, P.R. China; Erin J.C. Arsenault Fellow (2014-5) at the Institute of Air and Space Law of McGill University. B.A./M.A./Ph.D. (Xi'an Jiaotong Univ.). ORCID: http://orcid.org/00000001-8238-8368. The author may be contacted at: jinyuan.su@hotmail.com / Address: School of Law, Xi'an Jiaotong University, 28 Xianning West Road, Xi'an, Shaanxi 710049, P.R. China.

DOI: http://dx.doi.org/10.14330/jeail.2016.9.2.05 


\section{Introduction: The Need for Active Debris Removal}

Human exploration and use of outer space has not only made enormous contributions to the welfare of society, but has also resulted in a large number of debris in orbit. The US Space Surveillance Network ("SSN") currently tracks around 23,000 objects that are larger than $10 \mathrm{~cm}$ in diameter. ${ }^{1}$ Most of these tracked objects are debris residing in the busy Low Earth Orbits ("LEO”), i.e. orbits within 2,000 km of the Earth's surface. ${ }^{2}$ Their high travel speed makes space debris a threat to active spacecraft and human space missions. Their 'natural decay' relies on the atmospheric drag, and ranges from years to centuries depending on the altitude they orbit at. ${ }^{3}$

Space debris were not a major environmental concern in the early stage of space exploration and use. The treaties concluded then thus did not prescribe substantial obligations of environmental protection upon States. ${ }^{4}$ The most relevant limitations in this regard are perhaps the requirements of paying 'due regard,' avoiding 'harmful contamination,' and conducting 'consultations' as found in Article IX of the Outer Space Treaty. ${ }^{5}$ In the subsequent practice of States Parties, however, the creation of space debris has been seldom regarded as a violation of the 'due regard' principle. ${ }^{6}$ This practice, albeit tacit, has the effect of establishing an agreement of the parties on a strict interpretation of the principle. ${ }^{7}$ Although space debris were arguably a new form of such 'harmful contamination' of outer space, ${ }^{8}$ States Parties were only obliged to 'avoid' it and adopt 'appropriate' measures 'where necessary.' vague and subjective terms make it difficult to assess whether there is a violation. ${ }^{10}$ Provisions relating to consultations had never been directly used and invoked, ${ }^{11}$

1 Secure World Foundation, Space Sustainability: A Practical Guide 8-9 (2014), available at https://swfound.org/ media/121399/swf_space_sustainability-a_practical_guide_2014_1_.pdf(last visited on Oct. 26, 2016).

2 NASA, Orbital Debris Frequently Asked Questions, available at http://www.nasa.gov/news/debris_faq.html (last visited on Oct. 26, 2016).

$3 \quad I d$.

4 See, e.g., Treaty on Principles Governing the Activities of States in the Exploration and Use of Outer Space, including the Moon and Other Celestial Bodies of 1967, 610 U.N.T.S. 205, 6 I.L.M. 386 (entered into force on Oct. 10, 1967) [hereinafter Outer Space Treaty], art. I(2).

5 Outer Space Treaty art. IX.

6 On China's fragmentation of its FY-1C in 2007, e.g., protests by other States were more concerned with the lack of consultations. For details, see infra note 11.

7 Vienna Convention on the Law of Treaties of 1969, 1155 U.N.T.S. 331, art. 31(3)(b).

8 S. Marchisio, Article IX, in Cologne Commentary on Space Law (vol.1) 177 (S. Hobe et al. eds., 2009).

9 Outer Space Treaty art. IX.

10 L. Viikari, The Environmental Element in Space Law: Assessing the Present and Charting the Future 61 (2008).

11 R. Jakhu, Legal Issues of Satellite Telecommunications, the Geostationary Orbit, and Space Debris, 5 InT'L J. SPACE 
prior to the US activation of consultations with other space-faring countries before bringing down its USA-193 in 2008.

Space debris did not become a matter of major concern until the 1970s, when warnings of increased probability of satellite collisions were issued due to the so-called 'Kessler Syndrome."12 The issue was then discussed extensively at the intergovernmental level, in particular by the UN Committee on the Peaceful Uses of Outer Space ("COPUOS"). In 2002, the Inter-Agency Space Debris Coordination Committee ("IADC"), an international governmental forum between major national space agencies, adopted a set of guidelines designed to mitigate the growth of orbital debris. ${ }^{13}$ A similar set of guidelines were adopted by the COPUOS in June $2007^{14}$ and approved by the UN General Assembly in January 2008. ${ }^{15}$ The formation of the two sets of guidelines took a bottom-up approach with national and regional efforts predating international efforts. ${ }^{16}$

Mere mitigation, however, appears insufficient to keep space environment sustainable. Studies indicate that collisions among existing objects will force the LEO population to increase, even without any new launch. ${ }^{17}$ Efforts have been made in the technological arena in response to threats posed by space debris. E.g., conjunction analysis is made possible by Space Situational Awareness ("SSA"), to predict when and where satellites might encounter debris. Space objects with a high probability of

Politics \& PoL'y 194 (2015), available at http://www.tandfonline.com/doi/full/10.1080/14777620701580828. Some States alleged that China failed to fulfill the consultation obligation in the FY-1C fragmentation. See T. Hitchens, USSino relations in Space: From "War of Words" to Cold War in Space, 3 ChINA SECURITY 23 (2007). However, neither the US nor the former Soviet Union held international consultations prior to testing Anti-Satellite weapons during the Cold War. See M. Mineiro, FY-1C and USA-193 ASAT Intercepts: An Assessment of Legal Obligations under Article IX of the Outer Space Treaty, 34 J. SPACE L. 345 (2008), available at http://www.spacelaw.olemiss.edu/jsl/pdfs/backissues/js1-34-2.pdf (all last visited on Oct. 26, 2016).

12 D. Kessler \& B. Cour-Palais, Collision Frequency of Artificial Satellites: The Creation of a Debris Belt, 83 J. Geophysical Res. 2637 (1978), available at $\mathrm{http} / /$ webpages.charter.net/dkessler/files/Collision\%20Frequency.pdf (last visited on Oct. 26, 2016).

13 IADC Space Debris Mitigation Guidelines, IADC Action Item No 22.4 [hereinafter IADC Guidelines], available at http://www.iadc-online.org/index.cgi?item=docs_pub (last visited on Oct. 26, 2016).

14 UN Office for Outer Space Affairs, Space Debris Mitigation Guidelines of the Committee on the Peaceful Uses of Outer Space (2010) [hereinafter COPUOS Guidelines], available at http://www.unoosa.org/pdf/publications/st_ space_49E.pdf (last visited on Oct. 26, 2016).

15 International Cooperation in the Peaceful Uses of Outer Space, G.A. Res. 62/217, U.N. Doc. A/RES.62/217, ๆ 26 (Dec. 22, 2007), available at http://www.unoosa.org/pdf/gares/ARES_62_217E.pdf (last visited on Nov. 3, 2016).

16 Jinyuan Su, Control over Activities Harmful to the Environment, in Routledge HandBook of Space Law 77-9 (R. Jakhu \& P. Dempsey eds., 2017, forthcoming).

17 J.-C. Liou \& N. Johnson, Risks in Space from Orbiting Debris, 311 SCI. 340 (2006), available at http://science. sciencemag.org/content/311/5759/340. See also J.-C. Liou \& N. Johnson, Instability of the Present LEO Satellite Populations, 41 Advances IN Space Res. 1046 (2008), available at http://www.sciencedirect.com/science/article/pii/ S0273117707004097 (all last visited on Oct. 26, 2016). 
collision may be maneuvered to avoid collision. The analysis, however, is not always accurate and a maneuver would shorten the service of satellites in orbit. ${ }^{18}$ Another alternative is hardening space objects to shield them against the impact of debris. However, this can only be effective in collisions with objects smaller than $1 \mathrm{~cm} .{ }^{19}$

Today, the amount of space debris is fast growing. ${ }^{20}$ Recent analysis indicates that even with a 90 percent implementation of the commonly-adopted mitigation measures, the LEO debris population is expected to increase by an average of 30 percent in the next 200 years. ${ }^{21}$ It is thus recommended that aggressive measures such as ADR should be considered. ${ }^{22}$

Various concepts have been proposed for debris removal, some under development. The EPFL's Center for Space Engineering in Switzerland recently announced its plan to launch CleanSpace One satellite in 2018 to grab and de-orbit SwissCube, a $10 \mathrm{~cm}$ cubesat in orbit. ${ }^{23}$ Researchers at RIKEN in Japan proposed installing a laser cannon on the ISS to shoot down small debris up to a maximum size of about a centimeter. ${ }^{24}$ Chinese researchers also called for the development of space debris detection and removal technology based on the space station platform. ${ }^{25}$

The primary purpose of this research is to identify potential legal barriers to the future implementation of ADR, and to seek possible ways forward to overcome

18 NASA Orbital Debris Program Office, Orbital Debris Collision Avoidance, available at http://orbitaldebris.jsc.nasa. gov/protect/collision_avoidance.html (last visited on Oct. 26, 2016).

19 B. Weeden, Overview of the legal and policy challenges of orbital debris removal, 27 SPACE POL'Y 40 (2011), available at http://www.sciencedirect.com/science/article/pii/S0265964610001268 (last visited on Oct. 26, 2016).

20 J.-C. Liou, N. Johnson \& N. Hill, Controlling the Growth of Future LEO Debris Populations with Active Debris Removal, 66 Acta Astronautica 648 (2010), available at http://www.sciencedirect.com/science/article/pii/ S0094576509003981 (last visited on Oct. 26, 2016).

21 IADC Working Group 2, Stability of the Future LEO Environment, Jan. 2013, IADC-12-08, REv. 1, at 17, available at http://www.iadc-online.org/Documents/IADC-2012-08,\%20Rev $\% 201, \% 20$ Stability $\% 20$ of $\% 20$ Future $\% 20 L E O \% 20$ Environment.pdf (last visited on Oct. 26, 2016).

22 Id.

23 E. Ackerman, Swiss “Pac-Man” Satellite to Gobble Up Space Junk in 2018, IEEE Spectrum, July 9, 2015, available at $\mathrm{http}$ //spectrum.iee.org/tech-talk/aerospace/satellites/swiss-pacman-satellite-to-gobble-up-space-junk-in-2018?utm content=buffer8aff2\&utm_medium=social\&utm_source=linkedin.com\&utm_campaign=buffer (last visited on Oct. 26, 2016).

24 E. Ackerman, Proposal Would Put Laser Cannon on ISS to Blast Space Junk, IEEE Spectrum, Apr. 23, 2015, available at http:/spectrum.iee.org/tech-talk/aerospace/space-flight/proposal-would-put-laser-cannon-on-iss-to-blast-space-junk (last visited on Oct. 26, 2016).

25 Jianchao Jiao, Guoxian Zheng \& Yun Su, Space Debris Detection and Removal Based on Space Station Platform 基于 空间站平台的空间碎片探测与清除技术, 436 SPACE INT’L 国际太空 53-6 (2015), available at http://d.wanfangdata. com.cn/periodical/gjtk201504013. See also Xibin Cao, Feng Li, Jinxiu Zhang \& R. Muriel, Development status and tendency of active debris removal 空间碎片天基主动清除技术发展现状及趋势, 37 J. NAT'L U. DefENSE TeCH. 国防科技大学学报 117-20 (2015), available at http://journal.nudt.edu.cn/wap/ch/reader/view_abstract.aspx?file_ no=201504020\&flag=1 (all last visited on Oct. 26, 2016). 
these legal barriers. This paper is composed of four parts including Introduction and Conclusion. Part II will address legal barriers in the way of proposed ADR technologies. Part III will explore various ideas that could be taken into consideration to chart a course forward from the status quo.

\section{Potential Legal Barriers}

While the proposed ADR technologies clearly need further improvement to be technologically feasible and economically viable, a number of legal issues have emerged.

\section{A. The Lack of A Legally Binding Definition of Space Debris}

The term 'space debris' does not appear in any of the UN treaties on outer space. The IADC Guidelines, which are not legally binding, define them as "all man-made objects including fragments and elements thereof, in Earth orbit or re-entering the atmosphere, that are non-functional. ${ }^{26}$ The same definition was adopted by the COPUOS. ${ }^{27}$ The term "man-made objects" in the definition should be distinguished from 'space objects' appearing in the outer space treaties. The latter term is not defined, but it is prevalently regarded as including not only integral space objects, but also "component parts of a space object as well as its launch vehicle and parts thereof." 28

The functionality-based definition of space debris appears to be adequate for the implementation of space debris mitigation which is currently voluntary and confined to the scope of one's own space activities. Its limits may be tested in the context of ADR depending on specific rights and obligations contemplated. The definition is probably sufficient if debris are to be removed by the State creating them on a voluntary basis. However, if ADR is to become a legal obligation of States, this definition may be disputed, as removal entails costs and a non-functional space object is not necessarily valueless. Similarly, the definition may be disputed if the

26 IADC Guidelines, $₫ 3.1$.

27 COPUOS Guidelines, 1.

28 Outer Space Treaty art. VII. See also Convention on International Liability for Damage Caused by Space Objects of 1972, 961 U.N.T.S. 187, 10 I.L.M. 965 (1971) [herein after Liability Convention], art. I(d); Convention on Registration of Objects Launched into Outer Space of 1975, 1023 U.N.T.S. 15; 28 U.S.T. 695; 14 I.L.M. 43(1975) [hereinafter Registration Convention], art. I(b). 
right of ADR by States other than those creating them is contemplated. In such a situation, the characterization of a non-functional yet integral space object as a piece of debris is hence giving other States the freedom to remove it. However, this right would be also disputed, due to its possible intellectual property and military values.

\section{B. Possible Infringement upon Other States' Sovereign Jurisdiction or Ownership}

Space debris are ipso facto "man-made objects." It will arguably fall within the scope of 'space objects.' Inactive or dead space objects, whereas generally believed to remain space objects, ${ }^{29}$ would be regarded as space debris simultaneously as per the IADC/COPUOS definition. ${ }^{30}$ Fragments of space objects may be also considered space objects, because they were the component parts of space objects. ${ }^{31}$ A space object may cease to exist when it is disintegrated or destructed. In that case, the State of registry may be regarded as losing its jurisdiction and control over them, as it cannot technically fulfill the obligation of controlling them. This argument, albeit laudable in the context of ADR, seems to be asymmetric to the allocation and determination of responsibility and liability for damages caused by debris under existing international space law. ${ }^{32}$

It follows that other States are not always free to remove space debris characterized as such based on their non-functionality. According to existing international space law, unconsented removal may constitute an infringement upon the sovereign jurisdiction. The Outer Space Treaty provides that a State of registry shall "retain jurisdiction and control over such object, and over any personnel thereof, while in outer space or on a celestial body. ${ }^{, 33}$ In principle, the State of registry is the launching

29 Jakhu, supra note 11, at 194. See also B. Cheng, Studies In InTernational Law 506 (1997); Siqing Li, Obligation and legal basis of inactive satellite removal: ESA Envisat Satellite's removal 弃星移除的义务性及合法性问题一从欧 盟弃星 Envisat 谈起, 26 J. Peking U. Aeronautics \& Astronautics (Social Sciences Edition) 北京航空航天大学学 报 (社会科学版) 35 (2013), available at http://d.wanfangdata.com.cn/periodical/bjhkhtdxxb-shkxb201302007 (last visited on Oct. 26, 2016).

30 IADC Guidelines, $₫ 3.1$; COPUOS Guidelines, 1.

31 Jakhu, supra 11, 194. See also Huan Yu, Legal Study on Active Removal of the Space Debris 空间碎片主动移除法 律规制研究 18-9 (Harbin Institute of Technology, 2014).

32 Guoyu Wang, The jurisdiction of space debris and the legal basis of active space debris removal 空间碎片管辖权及主 动清除的法律依据, 16 J. BeIJNG InSTITUTE OF TECH. (Social Sciences Edition) 北京理工大学学报 (社会科学版) 106 (2014), available at $\mathrm{http} / / /$ journal.bit.edu.cn/sk/ch/reader/view_abstract.aspx?file_no=20140616; A. Soucek, Legal and practical considerations of registering constellations and space debris, IISL/ECSL Symposium on "40 years of entry into force of the Registration Convention: Today's practical issues," Apr. 4, 2016, available at http://www.unoosa.org/ documents/pdf/copuos/lsc/2016/symp-01.pdf (all last visited on Oct. 26, 2016).

33 Outer Space Treaty art. VIII. 
State, ${ }^{34}$ which is defined as "(a)(i) A State which launches or procures the launching of a space object," and "(a)(ii) A State from whose territory or facility a space object is launched." 35 This formula is regarded as implying not only 'obligations' but also 'rights. ${ }^{, 36}$ The State of registry is thus entitled to exercise sovereign jurisdiction over the space object.

Un-consented removal may also constitute an infringement upon the ownership of other States and even amount to threat or the use of force. The Outer Space Treaty recognizes that the ownership of objects launched into outer space is not affected by their presence in space. ${ }^{37}$ To remove arbitrarily a foreign State's governmental space objects, even their component parts, is hence a deprivation of the ownership thereof. The removal of military space objects may, at least in rare cases, amount to threat or use of force prohibited by the UN Charter. ${ }^{38}$ According to General Assembly Resolution 3314 (XXIX), attacks by a State's armed forces on the land, sea, or air forces or marine and air fleets of another State belong to the category of "acts of aggression." ${ }^{39}$ It is thus arguable that an attack by a State's armed forces on the "space forces' or 'space fleets' of another State may equally amount to aggression.

Unconsented debris removal by private operators may give rise to State responsibility, as well. As a general principle of international law, there is an "internationally wrongful act" of a State when a conduct consisting of an action or omission is attributable to the State under international law, and constitutes a breach of an international obligation of the State. ${ }^{40}$ However, as a rule of lex specialis, the Outer Space Treaty prescribes that States Parties shall bear international responsibility for national activities in outer space, irrespective of such activities being carried on by either governmental agencies or non-governmental entities. ${ }^{41}$

The above interpretation of outer space treaties is strictly loyal to the texts. An agreement regarding the interpretation otherwise, however, may be established between States Parties by their subsequent practice, if States predominantly refrain from protesting when fragments of their space objects are removed by other States

34 Registration Convention art. II (1).

35 Id. art. I(a); Liability Convention art. I (b).

36 B. Schmidt-Tedd \& S. Mick, Article VIII, in Cologne Commentary on Space Law (vol.1), 156-8 (S. Hobe et al. eds., 2009).

37 Outer Space Treaty art. VIII.

38 U.N. Charter art. 2(4).

39 Definition of Aggression, G.A. Res. 3314 (XXIX), annex, art. 3(d).

40 Draft Articles on Responsibility of States for Internationally Wrongful Acts, art. 2, [2001] II(2) Y.B. Int'1 L. Comm'n [hereinafter ILC Draft Articles].

41 Outer Space Treaty art. VI. 
without consent. This is unlikely to happen, however, when integral space objects reaching their end of life are concerned.

\section{Possible Liability for Damage Caused in ADR Operations}

It seems debatable as to whether space debris fall within the scope of space objects, thereby remaining under the jurisdiction and control of the State of registry. However, rules regarding the attribution of liability for damages caused by space debris is clear. Pursuant to the Outer Space Treaty, the launching State is internationally liable for damage to another State Party or to its natural or juridical persons by such object or its component parts on the Earth, in air or in outer space. ${ }^{42}$

Article VII of the Outer Space Treaty was then elaborated by the Liability Convention, which stipulates that: "A launching State shall be absolutely liable to pay compensation for damage caused by its space object on the surface of the Earth or to aircraft in flight." ${ }^{, 43}$ For such damage, liability can be legitimately established, as long as the launching State can be identified and the causal link between the damage and the activity can be proved. In 1978, Cosmos 954, a nuclear-powered satellite owned by the then Soviet Union (USSR), was disintegrated with hazardous radioactive debris scattered over a large area in Northern Canada. Negotiations concluded that the Government of the USSR should pay the Government of Canada three million Canadian dollars in full and the final settlement of all matters connected with the disintegration. ${ }^{44}$ It was pursuant to Article II of the Liability Convention, Article VII of the Outer Space Treaty, and general principles of international law, that Canada presented the claim. ${ }^{45}$ Although the settlement was not made through judicial proceedings, the legal grounds articulated by Canada are valid and seemed to be accepted by the USSR.

The Liability Convention also provides that in the event of damage being caused elsewhere than on the surface of the Earth to a space object of one launching State or to persons or property on board such a space object by a space object of another launching State, the latter shall be liable only if the damage is due to its fault or the fault of persons for whom it is responsible. ${ }^{46}$ In practice, however, it is difficult

42 Id. art. VII.

43 Liability Convention art. II.

44 Settlement of Claim between Canada and the Union of Soviet Socialist Republics for Damage Caused by "Cosmos 954," Canadian Department of External Affairs Communiqué No. 27, Released on April 2, 1981, art. I, available at http://www.jaxa.jp/library/space_law/chapter_3/3-2-2-1_e.html (last visited on Oct. 26, 2016).

45 Id.

46 Liability Convention art. III. 
to prove fault due to the lack of traffic rules in outer space. This is evidenced by discussions ensuring the collision between Cosmos-2251 and Iridium-33 in 2009. Russia asserted that it did not have an obligation under international law to dispose of the derelict Cosmos-2251 and placed fault for the incident on Iridium LLC's failure to maneuver Iridium-33 so as to avoid the collision. Responding to Russia, however, Iridium LLC contended that it did not have an obligation to avoid the collision even if it was aware that such a collision would occur. ${ }^{47}$ As neither side of the incident sought compensations, the international community missed an opportunity to clarify the rules regarding the attribution of fault in case of in-orbit collisions. Fault for damages caused in space would be even more difficult to prove if they are caused by small pieces of debris. ${ }^{48}$

The existing law of liability in outer space exerts little deterrence on space-faring countries to control the creation of space debris. Furthermore, it is counterproductive to implementing ADR tests and operations. First of all, unless removal technologies have achieved a high degree of reliability, some States would choose not to conduct reentry operations which can possibly cause damage on the Earth or in air, but to leave its space debris in orbit. In this scenario, possible damage caused by them in space does not necessarily incur liability due to the ambiguous concept of fault as mentioned above. Reentry operations authorized by the launching State, on the other hand, would give rise to several or joint liability with the implementing State. Second, in many cases, ADR requires trans-orbit maneuvering of satellites, which can pose threats to operative space objects. If damage is caused to them, or persons and properties on board, the State conducting ADR is arguably at fault thus liable for the damage according to the existing law, as the no-removal scenario probably would not have caused such damage.

The above conclusions regarding the attribution of liability for damages caused in ADR operations seem rather absurd, given the bona fide intention behind the efforts of ADR. The existing regime of liability was drafted in such way due to the victim orientation. ${ }^{49}$ Whereas this orientation shall be upheld today as it should be in the early stage of space exploration and use, more flexibility is needed in the application of rules in the context of ADR.

47 M. Listner, Iridium 33 and Cosmos 2251 Three Years Later: Where Are We Now?, Space Rev., Feb. 13, 2012, available at $\mathrm{http}: / / \mathrm{www}$. thespacereview.com/article/2023/1 (last visited on Oct. 26, 2016).

48 Jakhu, supra note 11, at 193.

49 J. Burke, Convention on the International Liability for Damage Caused by Space Objects: Definition and Determination of Damages after the Cosmos 954 Incident, 8 FordHAM InT’L L. J. 257 (1984), available at http://ir.lawnet.fordham.edu/ cgi/viewcontent.cgi? article $=1112 \&$ context $=$ ilj (last visited on Oct. 26, 2016). 


\section{The Implications for Space Arms Control}

Due to the technological similarity, some types of ADR systems would have inherent ASAT potential. ${ }^{50}$ The dual-use nature of such systems is thus an issue of concern for its possible damage to international security. The concept of a groundor space-based laser system proposed for the removal of mm-to-cm-sized debris, e.g., is thought to be facing more non-technical issues than others. ${ }^{51}$

Because of potential military implications of debris removal technologies and the worst presumption of national security concerned, the debris removal operations or tests, in particular those conducted unilaterally, could be taken as attempts to acquire ASAT capability. The recent orbital maneuvers and close approaches to space debris of Kosmos 2504 and Kosmos 2499 satellites, both launched by Russia, were suspected by some commentators to be tests of the ASAT systems or inspectors. ${ }^{52}$ China's similar maneuvers were likely taken by some as ASAT tests, but "experimental collection of space debris" by others. ${ }^{53}$ The technical profile of the rendezvous shows that Chinese maneuvers are more likely tests of an on-orbit satellite inspection capability that many countries are developing. ${ }^{54}$ In turn, such suspicions would inevitably exacerbate existing mistrust among States in the context of space security, thus posing additional impediments to the progress of space arms control.

In recent years, various space arms control initiatives have been proposed to reverse the course of a possible arms race in the outer space. One of them is the Draft Treaty on the Prevention of the Placement of Weapons in Outer Space, the Threat or Use of Force against Outer Space Objects ("PPWT"), jointly proposed by

50 M. Ansdell, Active Space Debris Removal: Needs, Implications, and Recommendations for Today's Geopolitical Environment, 21 J. PuB. \& INT'L AfF. 16 (2010), available at https://www.princeton.edu/jpia/past-issues-1/2010 (last visited on Oct. 26, 2016).

51 J.-C. Liou, Engineering and Technology Challenges for Active Debris Removal, 4 Progress IN PropUlsion Physics 743 (2013), available at http://www.eucass-proceedings.eu/articles/eucass/pdf/2013/01/eucass4p735.pdf (last visited on Oct. 26, 2016).

52 M. Wall, Is Russian Mystery Object a Space Weapon?, Space.com, Nov. 19, 2014, available at http://www.space. com/27806-russia-mystery-object-space-weapon.html. See also L. Grego, Russia's Small Maneuvering Satellites: Inspectors or ASATs?, Union of Concerned Scientists, Dec. 1, 2014, available at http://allthingsnuclear.org/russiassmall-maneuvering-satellites-inspectors-or-asats; M. Gruss, Maneuvering Russian Satellite Has Everyone's Attention, SpaceNews, July 17, 2015, available at http://spacenews.com/maneuvering-russian-satellite-has-everyones-attention (all last visited on Oct. 26, 2016).

53 L. David, Mysterious Actions of Chinese Satellites Have Experts Guessing, Space.com, Sept. 9, 2013, available at http://www.space.com/22707-china-satellite-activities-perplex-experts.html (last visited on Oct. 26, 2016).

54 B. Weeden, Dancing in the dark: the orbital rendezvous of SJ-12 and SJ-06F, SpACE REv., Aug. 30, 2010, available at http://www.thespacereview.com/article/1689/1 (last visited on Oct. 26, 2016). 
China and Russia at the Conference on Disarmament in $2008 .^{55}$ The challenge that dual-use space technologies pose to space arms control is addressed in PPWT in two aspects. First, any outer space object 'converted' for hostile purposes would become a weapon in outer space, hence its deployment is prohibited. ${ }^{56}$ Therefore, the deployment of ADR systems concealing hostile purposes will be banned. Some States and scholars have expressed concerns as to the feasibility of reaching a consensus on the term "weapons in outer space," given the dual-use nature of many spacecraft used for peaceful purposes. ${ }^{57}$ PPWT attempts to address this concern through its "non-threat or use of force" clause, which prohibits the use of any outer space object to attack or threaten to attack other objects therein. ${ }^{58}$ To use ADR systems to cause damage to satellites deliberately would thus be prohibited. The US has expressed a concern in that, as there are no prohibitions on the research, development, production and terrestrial storage of space-based weapons, there exists a possibility of a State's building and having in its inventory a readily deployable space-based ASAT or BMD capability. ${ }^{59}$

Another important initiative is the Draft International Code of Conduct for Outer Space Activities ("ICoC"), which was originally proposed by the EU and has recently gained considerable support from the US, Canada, Australia and Japan. ICoC is aimed to enhancing the safety, security, and sustainability of all outer space activities pertaining to space objects, as well as the space environment. ${ }^{60}$ It also addresses the issue of space arms control, although incidentally. It could be interpreted as prohibiting the testing and use of space-based ASATs, but not the research, development and deployment of them. ${ }^{61}$ The debris removal tests and

55 Draft Treaty on the Prevention of the Placement of Weapons in Outer Space, the Threat or Use of Force against Outer Space Objects (CD/1985) [hereinafter PPWT], art. I(b), available at https://documents-dds-ny.un.org/doc/UNDOC/ GEN/G14/050/66/PDF/G1405066.pdf?OpenElement (last visited on Oct. 26, 2016).

56 Id. art. II.

57 Principal Question and Comments on the Draft Treaty on Prevention of the Placement of Weapons in Outer Space and of the Threat or Use of Force against Outer Space Objects, and the Answers thereto (CD/1872), Question 9. For details, see F. von der Dunk, Cutting the bread, 29 SPACE POL'y 231 (2013), available at http://www.sciencedirect.com/science/ article/pii/S0265964613000817 (last visited on Oct. 26, 2016).

58 PPWT art. II.

59 Analysis of the 2014 Russian-Chinese draft "Treaty on the Prevention of the Placement of Weapons in Outer Space, The Threat or Use of Force against Outer Space Objects" (CD/1998), available at https://documents-dds-ny.un.org/ doc/UNDOC/GEN/G15/007/57/PDF/G1500757.pdf?OpenElement (last visited on Oct. 26, 2016).

60 Draft International Code of Conduct for Outer Space Activities of Mar. 31, 2014 [hereinafter ICoC], 1.1, available at http://www.eeas.europa.eu/non-proliferation-and-disarmament/pdf/space_code_conduct_draft_vers_31-march-2014_ en.pdf (last visited on Oct. 26, 2016). It reads: "The purpose of this Code is to enhance the safety, security, and sustainability..." See ICoC, at 3 (1. Purpose and Scope).

61 Jinyuan Su, Space Arms Control: Lex Lata and Currently Active Proposals, 5 Asian J. INT'L L. 15-6 (2015), available at https://www.cambridge.org/core/services/aop-cambridge-core/content/view/33AEE2235DA44A208E96C66DB03 
operations appear consistent with ICoC as they are carried out for imperative safety considerations and reduction of the creation of space debris. ${ }^{62}$ Eventually, ICoC does not seem to address effectively the dual-use issue and the development of break-out capability, either.

\section{Possible Ways Forward}

\section{A. International Coordination in Tracking and Cataloguing Space Debris}

In order to prevent or mitigate damages caused by pollution, it is essential to monitor the environment and identify possible pollution. In the law of the sea, States shall endeavor not only to "observe, measure, evaluate and analyze [...] the risks or effects of pollution of the marine environment," but also to "publish reports of the results [...] or provide such reports at appropriate intervals to the competent international organization, which should make them available to all States." addition, "[w]hen a State becomes aware of cases in which the marine environment is in imminent danger of being damaged or has been damaged by pollution, it shall immediately notify other States it deems likely to be affected by such damage, as well as the competent international organizations." ${ }^{\prime 4}$

No such international obligations, however, are imposed in the law of outer space. Instead, the last few years have witnessed the expansion of SSA activities and the growing willingness among States to share SSA data. As to the activities of SSA, e.g., the US Joint Space Operations Center ("JSpOC") had been performing conjunction analysis on the US government satellites. Through the 2009 collision between Cosmos-2251 and Iridium-33, it was realized that any major collision could put all spacecraft at risk and conjunction analysis is important to provide for all working satellites. ${ }^{65}$ The low accuracy catalogue of JSpOC is made available to

4B23D/S2044251315000223a.pdf/space-arms-control-lex-lata-and-currently-active-proposals.pdf (last visited on Oct. 26, 2016).

$62 \mathrm{ICoC} 4.2$.

63 United Nations Convention on the Law of the Sea of 1982, 1833 U.N.T.S. 3; 21 I.L.M. 1261 [hereinafter UNCLOS], arts. $204 \& 205$.

64 Id. art. 198.

65 R. Williamson, Assuring the Sustainability of Space Activities, 28 SPACE PoL'y 156 (2012), available at http://www. sciencedirect.com/science/article/pii/S0265964612000665 (last visited on Oct. 26, 2016). 
all registered users through the Space Track website. Also, access to information provided by the high accuracy catalogue can be obtained by entering into an agreement with the US Strategic Command ("USSTRATCOM"). Data from the high accuracy catalogue is also distributed in the event of a potential collision. ${ }^{66}$ Since the Iridium-Cosmos collision in 2009, the US has been informing all countries of potential collisions with hundreds of warnings each year. ${ }^{67}$ This has been taking place even between the US and China. Although the two States virtually have no other cooperation in space activities, the US Air Force will be likely to send such warnings directly to China's space operators, without a detour through the US State Department and the Chinese Ministry of Foreign Affairs. ${ }^{68}$ This latest development is remarkable noting that the US government maintains strict limitations on its spacecraft merchants and national space agency in the cooperation with China, and China has been reluctant to reveal contact information of its space operators. In spite of such defensiveness, both countries seem to be giving way, even if partially, to the commonly shared interest in ensuring the safety of their space operations and keeping the space environment sustainable for use.

In order to ensure the safety of their space operations, States should maintain independent SSA capabilities that match the level of their space exploration and use. Currently, the US and Russia maintain the most advanced SSA capacity, while China, Europe, Australia, India, Japan and South Africa have only limited capability of space surveillance. ${ }^{69}$ The continuous progress of emerging space-faring countries in space exploration and use calls for the simultaneous development of their indigenous SSA capability. ${ }^{70}$ Commercial satellite operators have also begun developing complementary coordination mechanisms, such as the Space Data Association

66 Space Safety \& Sustainability Working Group, Space Situational Awareness (SSS Educational Series 2012), at

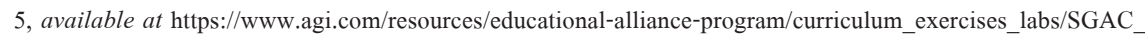
Space\%20Generation\%20Advisory\%20Council/space_situational_awareness.pdf (last visited on Oct. 26, 2016).

67 M. Aliberti \& S. Krasner, Governance in Space, Y.B. on Space Pol'y 2014: The Governance of Space 161 (C. AlEkabi et al. eds., 2016).

68 M. Gruss, U.S. to expedite orbital collision-avoidance warnings to China, SPACENEws, Dec. 5, 2014, available at http:// spacenews.com/42869us-to-expedite-orbital-collision-avoidance-warnings-to-china (last visited on Oct. 26, 2016).

69 Supra note 66, at 5-7.

70 E.g., China established its first space debris observation center in 2005. See China established 1st space trash observation center, ChINANews, Mar. 11, 2005, available at http://news.xinhuanet.com/english/2005-03/11/ content_2682880.htm. In 2015, China assembled the world's largest telescope Five-hundred-meter Aperture Spherical Telescope ("FAST"). See China assembles world's largest telescope in Guizhou, XINHUANET, July 24, 2015, available at http://www.china.org.cn/china/2015-07/24/content_36136455.htm. The FAST could be "a highly sensitive passive radar monitor satellites and space debris, which would be greatly helpful for China's ambitious space program." See China starts building world's largest radio telescope, XINHUANET, Dec. 26, 2008, available at http://www.china.org.cn/ china/sci_tech/2008-12/26/content_17016476.htm (all last visited on Oct. 26, 2016). 
("SDA") founded by Inmarsat, Intelsat and SES, due to the alleged fact that the US has preferred withholding its most accurate SSA data and information, as well as the methods used for processing them. ${ }^{71}$ The simultaneous progress of different countries and commercial entities in SSA would inevitably give rise to some degree of repetitiveness and inefficiency in resources utilization at the global level. But it would not only place States on an equal footing in SSA information sharing, but also lay a solid foundation for the possible establishment of a global unitary SSA mechanism.

To track space debris is one thing, to catalogue them is another. In the context of ADR, to catalogue space debris, in which the launching State can be identified, is no less important than simply to track them from the legal perspective. As mentioned above, the removal of space debris may require the consent of the State that retains the jurisdiction and control over them. The US SSN 'catalogued' approximately 17,000 objects larger than 5 to $10 \mathrm{~cm}$ in the Earth orbit as of September 2012. ${ }^{72}$ Each of the catalogued objects can be traced back to a break-up event and the launching State can be identified.

The current catalogue system is not complete, either. Albeit the most credible so far, it is ultimately a unilateral catalogue. It is recognized that there is a large number of similar-sized space objects that are tracked, but not catalogued. Also, it is virtually impossible to track debris smaller than $1 \mathrm{~cm}$ in size. ${ }^{73}$ The removal of space debris on a large scale thus requires the establishment of an international and more comprehensive catalogue of space debris.

The establishment of such an international catalogue is made possible by the registration of space objects launched into outer space as required by exiting international space law, in particular as far as inactive and dead space objects are concerned. The Registration Convention requires the launching State to register the space object, when it is launched into earth orbit or beyond, "by means of an entry in an appropriate registry." the Secretary-General of the United Nations" information concerning each space object carried on its registry, including the name of launching State or States, an appropriate designator of the space object or its registration number, date and

71 Supra note 67, at 162.

72 ESA, Space Debris: Frequently Asked Questions, available at http://www.esa.int/Our_Activities/Operations/Space Debris/FAQ_Frequently_asked_questions (last visited on Oct. 26, 2016).

73 Supra note 19, at 41.

74 Registration Convention art. II(1). 
territory or location of launch, and basic orbital parameters. ${ }^{75}$ The Registration Convention is complemented by the earlier General Assembly Resolution 1721B (XVI), where States launching objects into orbit or beyond are called upon to furnish information promptly to the COPUOS, through the Secretary-General, for the registration of launchings. ${ }^{76}$ Those States as the US and Russia ceased transmitting related information to the COPUOS while acceding to the Registration Convention. ${ }^{77}$ Some States have re-registered all their space objects under the Registration Convention. In this case, the space objects are removed from the Resolution Register to the Convention Register. ${ }^{78}$ Non States Parties to the Registration Convention, such as Azerbaijan, voluntarily transmitted information concerning space objects they launched into outer space according to the UNGA Resolution 1721B (XVI).

If all objects launched into outer space are registered and tracked, it is possible, at least theoretically, to catalogue most debris in outer space, as they will have already been registered before turning non-functional. The scenario, however, is not feasible currently. This is partly because there are technological barriers for SSA to track all space objects and many space objects launched into outer space were not registered.

The compliance of States and international organizations with the above obligations of registration is never universal. ${ }^{79}$ E.g., the registration ratio of space objects at the national and international levels was only 75 percent of the time between 2001 and 2003; it was down from 91 percent in 1991..$^{80}$ The UN Office for Outer Space Affairs ("UNOOSA") also warned recently that there is a growing divergence between 'space nations' and "States of registry," and there are functional space objects that are not registered almost each year. ${ }^{81}$ Multiple reasons have contributed to the dissatisfactory record of registration compliance. The Registration Convention has only received more accessions than the 1979 Moon Agreement

75 Id. art. IV(1).

76 International co-operation in the peaceful uses of outer space. G.A. Res. 1721 B (XVI) (Dec. 20, 1961), available at http://www.un.org/en/ga/search/view_doc.asp?symbol=A/RES/1721(XVI) (last visited on Oct. 26, 2016).

77 For registration submissions under Article IV of the Registration Convention and UNGA Resolution 1721 B (XVI), see United Nations Register of Objects Launched into Outer Space, available at http://www.unoosa.org/oosa/en/ spaceobjectregister/submissions/states-organisations.html (last visited on Oct. 26, 2016).

78 S. Pippo, Registration of Space Objects with the Secretary-General, The IISL-ECSL Symposium on "40 years of entry into force of the Registration Convention - Today's practical issues," Apr. 4, 2016, available at http://www.unoosa. org/documents/pdf/copuos/lsc/2016/symp-03.pdf (last visited on Oct. 26, 2016).

79 Report of the Chairman of the Working Group on the Practice of States and International Organizations in Registering Space Objects: Annex III to Report of the Legal Subcommittee on its forty-sixth session, held in Vienna from March 26 to April 5, 2007, UN Doc. A/AC.105/891 (May 7, 2007), at 31, ๆ 6, available at https://documents-dds-ny.un.org/ doc/UNDOC/GEN/V07/830/36/PDF/V0783036.pdf?OpenElement (last visited on Oct. 26, 2016).

80 Space Security Index 2010, available at http://spacesecurityindex.org/2010/10 (last visited on Oct. 26, 2016).

81 Supra note 78. 
among the five UN treaties of space law, ${ }^{82}$ whereas Resolution 1721B (XVI) is only recommendatory. At the international level, it is also due to the wide margin of discretion left to States by the term "as soon as practicable" stipulated in the Convention. ${ }^{83}$ In addition, some States have established a national registry, ${ }^{84}$ thereby rendering the registration impracticable. In the case of multiple launching States, an agreement may not have been arrived as to who should be the State of registry. ${ }^{85}$

Even if the Registration Convention is widely complied with, the information concerning space objects required by the international registration, which currently includes nodal period, inclination, apogee, perigee, and general function of the space object, $^{86}$ is probably too limited to accommodate the need of ADR. The information provided pursuant to Resolution 1721B (XVI) is usually no more detailed than that furnished under Article IV of the Registration Convention. It does not include the updated operating status of space objects launched into outer space. In addition, although the term 'space object' includes "component parts of a space object as well as its launch vehicle and parts thereof," State practice with regard to the registration of upper stage rockets is heterogeneous. E.g., China, Japan, and Russia register functional objects only, while France, India, and the US register upper stages of the launch vehicle as well as functional objects. ${ }^{87}$ Although the State of registry "may, from time to time, provide the Secretary-General of the United Nations with additional information concerning a space object carried on its registry" according to the Registration Convention, ${ }^{88}$ the term of 'may' entails little legal obligation in its ordinary meaning. The Outer Space Treaty also requires its States Parties conducting activities in outer space "to inform the Secretary-General of the United

82 As of 1 January 2016, the Registration Convention has only 62 ratifications, acceptance, approval accession or succession, 4 signatures, and 3 declarations of acceptance of rights and obligations. See COPUOS, Status of International Agreements relating to Activities in Outer Space (Jan. 1, 2006), at 1, available at http://www.unoosa. org/documents/pdf/spacelaw/treatystatus/AC105_C2_2016_CRP03E.pdf (last visited on Oct. 26, 2016). Here, ESA, EUMETSAT and EUTELSAT have declared their acceptance of rights and obligations of the Registration Convention.

83 Registration Convention art. IV(1).

8427 Member States to the Registration Convention and Organizations have notified the UN on the establishment of their national registries of objects launched into outer space as of April 8, 2016. See Convention on Registration of Objects Launched into Outer Space, available at http:/www.unoosa.org/oosa/en/spaceobjectregister/national-registries/index. html (last visited on Oct. 26, 2016).

85 Supra note 78.

86 Id.

87 N. Hedman, Registration of Space Objects with the United Nations, The UN/China/APSCO Workshop on Space Law on "The Role of National Space Legislation in Strengthening the Rule of Law," Beijing, China, Nov. 17-20, 2014, available at http://www.unoosa.org/documents/pdf/spacelaw/activities/2014/pres08E.pdf (last visited on Oct. 26, 2016).

88 Id. art. IV(2) [Emphasis added] 
Nations as well as the public and the international scientific community, to the greatest extent feasible and practicable, of the nature, conduct, locations and results of such activities." ${ }^{\prime 89}$ Notifications under this provision are usually more detailed than those furnished under the Registration Convention and Resolution 1721B (XVI). But the term "to the greatest extent feasible and practicable" leaves a wide margin of discretion on the part of States; only a very small number of them have submitted such notifications. ${ }^{90}$

The challenge faced in the registration of space objects were discussed extensively in the COPUOS, accumulating to the adoption of Resolution 62/101 in the UN General Assembly on December 17, 2007. This resolution includes recommendations regarding the adherence to the Registration Convention, the harmonization of practices, the achievement of the most complete registration of space objects, and actions following the change in supervision of a space object in orbit. ${ }^{91}$ More specifically, it recommends furnishing additional appropriate information to the Secretary-General on, among others, any change of status of operations (inter alia, when a space object is no longer functional). ${ }^{92}$ Such non-functional space objects will be regarded as space debris if the IADC/COPUOS definition is applied. Although integral space objects that are non-functional only take a very small part of all space debris, they pose the most significant threats as collisions of them would probably result in breakups and creation of a large number of smaller debris. Accordingly, the registration of non-functional space objects is essential for ADR. As requested by the resolution, UNOOSA prepared a model registration form to assist States and organizations in registering space objects. ${ }^{93}$ The form is currently used by 20 States of registry. ${ }^{94}$ UNOOSA commended that with the adoption of Resolution 62/101,

89 Outer Space Treaty art. XI.

90 For notifications under Article XI of the Outer Space Treaty, see United Nations Register of Objects Launched into Outer Space, available at http:/www.unoosa.org/oosa/en/spaceobjectregister/submissions/states-organisations.html (last visited on Oct. 26, 2016).

91 Recommendations on enhancing the practice of States and international intergovernmental organizations in registering space objects. G.A. Res. 62/101, U.N. Doc. A/RES/62/101 (Jan. 10, 2008), available at http://www.un.org/en/ga/ search/view_doc.asp?symbol=A/RES/62/101 (last visited on Oct. 26, 2016).

92 Id. ๆ 2(b)(ii).

93 UNOOSA, Registration Information Submission Form, available at http://www.unoosa.org/oosa/en/spaceobjectregister/ resources/index.html (last visited on Oct. 26, 2016). The form consists of four parts, namely: (a) information provided in conformity with the Registration Convention or Resolution 1721B (XVI); (b) additional information for use in the UN Register of Objects Launched into Outer Space as recommended in Resolution 62/101; (c) information relating to the change of supervision of a space object as recommended in Resolution 62/101; and (d) additional voluntary information for use in the UN Register of Objects Launched into Outer Space.

94 Supra note 78. 
there have been 'substantial changes' to the State practices of registry. ${ }^{95}$ Space-faring countries should be further encouraged to follow the recommendations. This seems to be a more practical path for the enhancement of registration of space objects than to seek an amendment to the Registration Convention, given that the making of 'hard' space law has been in stagnation since the signing of the 1979 Moon Agreement.

Dead and inactive space objects are not the only threat in outer space. As mentioned above, even debris as small as those in 1-10 cm range can cause deadly destruction to spacecraft. Currently, States do not have the obligation to register component parts and fragments of space objects and their launch vehicles. Operational and fragmentation debris are generally not registered, either. ${ }^{96}$ Although States are probably willing to register them, technological difficulties and high costs of removing small pieces of debris would render the registration meaningless. Therefore, the focus of international efforts should be on tracking such small-size debris. In addition, a sub-catalogue system should be established to include them, by which small-size debris should be beyond the jurisdiction and control of the State of registry, and can be freely removed if necessary and feasible. ${ }^{97}$ International consensus should also be reached, in that space debris whose owner can no longer be identified shall be included in this sub-catalogue.

\section{B. Voluntary, Delegated, and Un-consented Removal}

One should “clean up one's trash.” However, the legal obligation of States to recover pollution that they cause beyond national jurisdiction, remains contingent on their contractual consent. In the law of the sea, States Parties to the UNCLOS have the obligation in general to take measures that are necessary to prevent, reduce and control pollution of the marine environment. ${ }^{98}$ Coastal States of the exclusive economic zone ("EEZ") have the exclusive right to construct and to authorize and regulate the construction, operation and use of artificial islands, installations and structures. ${ }^{99}$ In this case, they also assume the obligation to remove any installations or structures which are abandoned or disused to ensure safety of navigation. ${ }^{100}$ The

\footnotetext{
95 Id.

96 P. Meredith, A Legal Regime for Orbital Debris: Elements of a Multilateral Treaty, in Preservation of NeAR-Earth Space for Future Generations 216 (J. Simpson ed., 2006).

97 It is proposed that small debris should be removed by collaboration between States Parties to a unitary space debris convention. See, e.g., Yu, supra note 31, at 27.

98 UNCLOS art. 194.

99 Id. art. 60(1).

100 Id. art. 60(3).
} 
Nairobi International Convention on the Removal of Wrecks obliges the registered owner to remove its shipwreck in the 'Convention area' of the 'Affected State' if it is determined to constitute a hazard. ${ }^{101}$ By contrast, Article IX of the Outer Space Treaty, even by a broad interpretation, does not include a legal obligation of debris mitigation, not to mention that of ADR.

Given that the practice of space debris mitigation has been following the 'soft law' approach, it is highly unlikely that States would accept the legally binding contractual obligation of ADR. Instead, States should be encouraged to remove space debris that they create. The common interest in maintaining the safety and sustainability of outer space would nevertheless give space-faring countries an impetus to conduct ADR when the need arises and cost effective measures are ready. In doing so, they may license private entities to carry out removal operations, or delegate other States with the technology to remove space debris under their jurisdiction and control. ${ }^{102}$ Draft Articles on Responsibility of States for Internationally Wrongful Acts provides: "Valid consent by a State to the commission of a given act by another State precludes the wrongfulness of that act in relation to the former State to the extent that the act remains within the limits of that consent." ${ }^{103}$ If necessary, the international community should consider establishing an international body in charge of ADR. Such an international body may actively seek for a State's permission to remove dangerous space debris under its jurisdiction and control. States should also be encouraged to relinquish jurisdiction and control over space objects that have reached the end of life, thereby allowing other States or the international community to remove them.

As mentioned above, un-consented removal of space debris, regardless of the size and compactness, are at least contrary to existing international space law in theory. It is argued that the jurisdiction and control that the State of registry has over space objects should be qualified by the principles of 'cooperation,' 'mutual assistance' and 'due regard'; and that if no action is taken by the State of registry for a threatening space object, the State whose space object is threatened should have

101 Nairobi International Convention on the Removal of Wrecks of 2007, 46 I.L.M. 697, art. 9. Article 1(1) of the Convention provides: 'Convention area' is "the exclusive economic zone of a State Party, established in accordance with international law or, if a State Party has not established such a zone, an area beyond and adjacent to the territorial sea of that State determined by that State in accordance with international law and extending not more than 200 nautical miles from the baselines from which the breadth of its territorial sea is measured."

102 J. Pelton, New Solutions for the Space Debris Problem 74 (2015). Pelton draws a distinction between jurisdiction and control over non-functional space objects.

103 ILC Draft Articles, art.20. 
the right to remove it without consent. ${ }^{104}$

In this connection, it should be noted that the wrongfulness of un-consented removal may be precluded in some exceptional cases. International law recognizes that the necessity for a State to safeguard an essential interest threatened by a grave and imminent peril may outweigh the international obligation breached. ${ }^{105}$ The invocation of necessity requires that the act be the only way for the State to safeguard an essential interest against a grave and imminent peril. ${ }^{106}$ Here, the act shall not seriously impair an essential interest of either the State(s) towards which the obligation exists, or the international community as a whole. ${ }^{107}$ Where there is an extremely high probability of collision between debris and an operating spacecraft, the latter's State of registry should initiate the process of consultations with that of debris under Article IX of the Outer Space Treaty. In the circumstance where there is no sufficient time for consultations, it may have the right to remove the debris without consent, depending on, inter alia, the probability of collision, the chance of active maneuver, the ratio of value between the threatened space object and the debris to be removed. Last but not the least, although the current space environment seems far from such an urgent point, it shall not be ruled out that there may be the need for the international community to seek a UN Security Council resolution, to determine space debris as a threat to international peace and security and to authorize the removal. Such an authorization can override obligations under the Outer Space Treaty, as in the event of a conflict between the obligations between the UN Members under the Charter and those under any other international agreement, the Charter based obligations shall prevail. ${ }^{108}$

If the above-mentioned sub-catalogue is established, the removal of small-size debris and debris for which the State of registry cannot be identified, need not be consented. On the one hand, small fragmentation and operational debris are free for removal as the States of registry have relinquished jurisdiction and control over them. An international consensus is not difficult to achieve on this matter, as they do not seem to possess significant military or intellectual property values. The challenge remaining is more technological; it is cost-effective to remove them. If State of registry can no longer be identified, on the other hand, debris should be viewed as

\footnotetext{
$104 \mathrm{Li}$, supra note 29 , at 35.

105 ILC Draft Articles, art. 25(1).

$106 \mathrm{Id}$.

107 Draft articles on Responsibility of States for Internationally Wrongful Acts, with commentaries, at 81-2, available at http://legal.un.org/ilc/texts/instruments/english/commentaries/9_6_2001.pdf (last visited on Oct. 27, 2016).

108 U.N. Charter art. 103
} 
abandoned properties, which usually can become the property of whoever finds it and takes possession of it first. ${ }^{109}$ A valid argument may be that the international community should have the right to freely dispose of them if they constitute a threat to public safety. ${ }^{110}$

\section{An International Debris Removal Fund}

Considering the presumably high costs and risks associated with ADR, it is proposed that an international fund should be created to provide the means to undertake orbital debris removal, and to cover the liabilities associated with debris removal. ${ }^{111}$ The necessity of establishing a debris removal fund was recognized by the Scientific and Technical Subcommittee of the COPUOS early in 1998, ${ }^{112}$ but it was not carried forward officially.

The creation of the fund is an important step in incentivizing public and private entities to invest in the research and development of debris removal technologies, by assuring them of the possibility of gaining revenues and clearing uncertainties associated with the liability issue. It could be used to cover, at least partially, the costs incurred in the course of ADR. If States can do it multilaterally it would significantly ease the concern over the dual-use nature of such activities. It could also be used to assist the indemnity, e.g., through commercial insurance, for possible damages caused in debris removal, thereby relieving potential operators from the concern that unsuccessful operations are to entail liabilities.

A question may follow on how financial contributions are spread in the establishment of such fund. State contribution amount should be based on either market-share responsibility for the debris currently in orbit, ${ }^{113}$ or the scale of power

109 L. Strahilevitz, Unilateral relinquishment of property, in ReSEARCH HANDBOOK ON THE ECONOMICS OF PROPERTy LAW 127 (K. Ayotte \& H. Smith eds., 2011). For details on the freedom of removing debris and inactive satellites whose state of registry is not identifiable, see Zhao Wang, Dongchun Yang \& Zhiyu Kang, Legal matters about space debris removal 空间碎片主动移除任务的相关法律问题, 28 J. PekING U. Aeronautics \& Astronautics (Social Sciences Edition) 北京航空航天大学学报(社会科学版) 46 (2015), available at http://edu.wanfangdata.com.cn/Periodical/Detail/ bjhkhtdxxb-shkxb201502008 (last visited on Oct. 26, 2016).

110 See, e.g., Harbors and Navigation Code of California, §1, 523(a)(1). Similar laws are found in other States as well. See, e.g., Fla. Stat. $\$ 823.11(3)$.

111 Supra note 102 , at 75.

112 Committee on the Peaceful Uses of Outer Space, Scientific \& Technical Subcommittee, Report on its 35th Session, Feb. 8-20, 1998, UN Doc. A/AC.105/697 (Feb. 25, 1998), at 103, available at http://www.unoosa.org/pdf/reports/ ac105/AC105_697E.pdf (last visited on Oct. 26, 2016).

113 M. Sundahl, Unidentified Orbital Debris: The Case for a Market-Share Liability Regime, 24 HASTINGS INT'L \& ComP. L. REv. 138-47 (2000), available at https://itigation-essentials.lexisnexis.com/webcd/app?action=DocumentDisplay\& crawlid=1\&srctype $=$ smi\&srcid=3B15\&doctype $=$ cite $\&$ docid $=24+$ Hastings + Int $\% 271+\% 26+$ Comp. + L. + Rev. $+125 \&$ ke y=63b6d25ba3c3441a51e5b77d5bd67f16. See also M. Williamson, Space: The Fragile Frontier 270 (AiAa 2006); 
States have in space. ${ }^{114}$ Also, every future space launch should include an additional fee that will be sent to the fund. ${ }^{115}$ However, it is unclear whether space powers are willing to undertake the greatest financial obligation for their space debris removal. As major industrial countries agreed to take obligations in the negotiations of reducing greenhouse gas emission, major space-faring countries in the context of outer space, would have a decisive impact on the outcome. The US recently accepted that such a solution would conform to its national security interest, albeit burdensome on it in the short term. ${ }^{116}$ This observation also holds true for each space-faring country.

Another challenge in spreading financial contributions is a possible proposition of 'military exception' from States. Namely, debris created by military activities shall be exempted in the consideration of distribution. This proposition has prevailed in the negotiation of many international environmental agreements. ${ }^{117}$ The undergoing consultations of ICoC cannot escape from the similar resistance from some States that called for limiting its scope of the code to civil and commercial uses. ${ }^{118}$

\section{Space Arms Control and International Cooperation}

International security and environmental protection are twin impetuses for arms control. Both Chinese and the US ASAT tests were the first of their kind since the 1980s, when the US and the former Soviet Union, after a series of tests during the Cold War, ceased doing so. The tests prompted the concern that they might be the beginning of a new round of arms race in outer space and the debris created might render the Earth orbits un-usable. Although no such debris-generating test was implemented thereafter, it is undeniable that militarization of outer space continues.

J. Imburgia, Space Debris and Its Threat to National Security: A Proposal for a Binding International Agreement to Clean Up the Junk, 44 Vanderbilt J. Transnat'L L. 629-32 (2011), available at https://wp0.its.vanderbilt.edu/wpcontent/uploads/sites/78/Imburgia-FINAL-CR-pdf.pdf (all last visited on Oct. 26, 2016).

114 Xiangchen Wang, Analysis on legal issues of active debris removal 空间碎片主动移除法律问题分析, 20 THEORY RESEARCH 学理论 115 (2014), available at http://www.cnki.com.cn/Article/CJFDTotal-LBYT201420052.htm (last visited on Oct. 26, 2016).

115 Williamson, supra note 113, at 270; Imburgia, supra note 113, at 630.

116 Imburgia, supra note 113, at 630.

117 Article 236 of the UNCLOS provides: "The provisions regarding the protection and preservation of the marine environment do not apply to any warship, naval auxiliary, other vessels or aircraft owned or operated by a State and used only on government non-commercial service."

118 Annotations to the 31 March 2014 Version of the Draft International Code of Conduct for Outer Space Activities based on comments made in the context of the third round of Open-ended Consultations held in Luxembourg on May 2728, 2014, available at http://www.eeas.europa.eu/archives/docs/non-proliferation-and-disarmament/pdf/space_code_ conduct_draft_vers_31-march-2014_en.pdf(last visited on Oct. 26, 2016). 
While arms control primarily addresses the issue of inter-State security, ADR is a response to one of the common challenges to the global society. In either respect, testing its limits, existing international space law need to be strengthened to cope with the challenges. On the one hand, it is insufficient to prevent an arms race in outer space effectively, while, on the other hand, it is somewhat counterproductive to the implementation of space debris removal. The international community should continue to address both inter-State security issues through arms control, and common security issues through international cooperation.

Current space arms control initiatives such as PPWT and ICoC, represent important steps for strengthening legal rules on the prevention of an arms race in outer space. Unfortunately, their progress has been hampered by the long-lasting disagreement among major space-faring countries on the primary-level obligations of space arms control, i.e. the prohibition of space-based weapons and/or terrestrialbased ASATs, and the technical difficulty of verification. The debate on space arms control is waiting for a proposal that prohibits both space-based weapons and ASATs. If States are insisting on effective verification of space arms control, they should realize that a progressive approach, starting with a treaty with imperfect verifiability, will bring more security to the world than the laissez faire scenario. ${ }^{119}$

Arms control is one of the primary methods to ensure international peace and security. This legal constraint is ultimately based on international cooperation that provides the panacea for long-lasting international peace and security. International cooperation in all fields of space exploration and use between all space-faring countries is probably an unreasonable expectation in the near future. Such cooperation, however, should at least be promoted in the areas where collective actions are needed to cope with common challenges to space security, such as the threats posed by the increase of space debris. Debris removal project carried out by multilateral cooperation under international law will help dilute mistrust and enhance confidence among States. It will finally make a great contribution to space arms control. 


\section{Conclusion}

The existing international law of outer space was made at the climax of the Cold War when the primary concern was the possible dominance of one bloc over the other, in and from space. Common challenges to the international community in outer space, such as threats posed by man-made debris and natural asteroids, did not emerge or become widely recognized for a considerable period of time after their entry into force. No wonder a 'loyal' application of the existing norms in the context of ADR, as in asteroid mitigation, often leads to absurd outcomes that hinder its smooth implementation. The climate of international politics has apparently become much milder with the end of the Cold War and even more so today, where States have become unprecedentedly interdependent. Although the functional scope of existing law is tested in many aspects by new developments, the fundamental framework remains essential in the international rule of law of outer space and shall not be subject to radical change. This shall not, of course, prevent us from devising policy innovations for the purpose of implementing ADR, including a more coordinated tracking of space debris, the enhancement of registration of space debris, the establishment of an international catalogue of space debris, the creation of an international fund, and the promotion of international cooperation. 